\title{
Teatro político nos anos Brejnev. A Tagánka
}

\section{Politic theatre in Brejnev era. The Tagánka}

Béatrice Picon-Vallin ${ }^{1}$

Tradução: Edélcio Mostaço ${ }^{2}$ 
Resumo

O artigo evoca o encenador russo Yuri Liubímov, fundador do Teatro da Tagánka, grupo que atravessou, sob forte censura, os anos de chumbo do regime soviético. Desenvolvendo forte relação com sua plateia o grupo resistiu, até o surgimento da perestróika, como uma referência internacional contra o arbítrio.

Palavras-chave: Liubímov; Tagánka; censura; URSS

\section{Abstract}

The article focuses the Russian director Yuri Liubímov, founder of Tagánka Theatre, troupe that cruises under rough censorship the Cold War period. Developping a great relation with his audiences, the troup remais untill the perestróika period as an international reference against force.

Keywords: Liubímov;Tagánka; Censorship; URSS

ISSN: 1414.5731

E-ISSN: 2358.6958

\footnotetext{
${ }^{1}$ Diretora de pesquisas no CNRS (Centre National de la Recherche Scientifique), professora de história do teatro no Conservatório Nacional Superior de Arte Dramática de Paris, diretora das coleções Arts du spectacle (CNRS), thxx (L'Age d'Homme, Lausanne) e Mettre en scène (Actes Sud-Papiers, Arles). Especialista em teatro do século XX, suas pesquisas incluem a história do teatro russo, as questões relativas ao teatro europeu do século XX, à encenação, ao trabalho do ator, compreendendo ainda as relações entre a cena e as imagens (cinema, vídeo, novas tecnologias), a pedagogia do trabalho da cena e a relação com as neurociências. Tem colaborado com as principais publicações especializadas em teatro, na França, na Rússia e em diversos outros países.

${ }^{2}$ Professor Doutor Titular da Universidade do Estado de Santa Catarina (UDESC), atuando junto ao Programa de Pós-Graduação em Teatro (PPGT-CEART).c2emo@udesc.br
} 
Não há teatro sem escândalo Nikolai Erdman

O teatro é uma arte mas, ao mesmo tempo, algo mais que uma arte. Vsevolod Meyerhold

Entre 1964 e 1984, o Teatro da Tagánka foi um dos "bastiões" da vida cultural moscovita e soviética, uma cena em direta relação com seu tempo, um teatro-lenda antes mesmo de ter tempo de passar à história. Em sua sala de quase 500 lugares, estabeleceu com um amplo círculo de espectadores uma forte relação emocional e intelectual que não se deu por nenhuma intimidade sentimental, mas que era sobretudo da ordem pública. Criada sorrateiramente por Yuri Liubímov após o fim do degelo, a Tagánka carregou - durante muito tempo - todo o potencial criativo desse período.

À medida em que se posicionou desde o início contra a estética dominante e onde, através de sua leitura de $A$ alma boa de Setsuan, de Bertolt Brecht ${ }^{3}-$ um verdadeiro "cavalo de Tróia" que a permitiu voltar às origens ocultadas das vanguardas soviéticas dos anos 20 -, ela exibiu os princípios do jogo exteriorizado, não psicológico e com uma mise en scène metafórica, a Tagánka afrontou, sob a condução de Liubímov, a rigidez e o absurdo totalitarismo pós stalinista. Ela se tornou política sem se colocar diretamente no terreno político.

A sucessão de seus espetáculos vai, em seguida, se aparentar a um sempre retomado combate pela existência, à imagem de Vivo, adaptado de um conto de Boris Mojaev, um espetáculo bem batizado e colocado em cena em 1968 e constantemente interditado, interditado todos os anos, e que vai conhecer sua estreia somente vinte anos após - fato único na história do teatro. Desde suas origens, a Tagánka se apresenta no contexto soviético como um "teatro de escândalos" que não para de lutar contra os "órgãos" políticos e culturais e que, sem a ajuda de uma imprensa amordaçada, mas contando com o diz-que-diz e com o boca-a-boca entre o público, ocupou perto de vinte anos o centro da vida teatral não somente da capital, mas de toda a Rússia, graças às numerosas turnês que vai efetivou.

Sem hesitar, Liubímov, então com 47 anos ao se tornar encenador, soube pilotar sua trupe numa zona de risco onde se inscreve toda sua história, fazendo obstinada resistência a todos os temores e diktats dos funcionários dos ministérios e do partido. Com buracos e remendos decorrentes da censura, suas cicatrizes, cada espetáculo foi marcado, de um lado, pelo fogo vermelho desses processos mutilantes e, de outro, por uma vontade de fazer recuar os limites para o "permitido". Ao conteúdo particular de cada um deles ajuntou-se, sempre, o público a escuta-los atentamente, na dramática aventura de suas criações, onde a plateia percebia um jogo terrível com os paradoxos do sistema soviético. Frank Castorff, então um encenador alemão em outro país do leste, a RDA, subinha que durante esses anos "o teatro viveu um status à parte. Era a única matéria onde se podia ser matreiro com o regime".

Matreiro. Estar "sob o fio". Entre 1964 e 1984 - data do exílio de Liubímov na Europa ocidental após a violenta crise que o colocou frente à frente, entre 1982 e

\footnotetext{
${ }^{3}$ É preciso dizer que Brecht era então pouco representado na URSS
} 
1984, com o poder soviético terminou numa tripla destituição: da direção do teatro, de sua nacionalidade e de seu pertencimento ao partido comunista -, a Tagánka teve casas lotadas todas as noites. Seu público podia passar noites inteiras fazendo fila na esperança de conseguir um ingressso. Ainda está no ouvido o refrão lancinante das súplicas no metrô (" $U$ va net lichni bilet") pelos bilhetes para saltar na estação Tagánka, em frente ao teatro... Ali, seus espectáculos não eram apenas acontecimentos culturais, mas episódios da vida política e social do país, não apenas representações em tardes memoráveis sob o ponto de vista artístico, mas também da vida individual de cada espectador.

É preciso, é claro, colocar os fatos em seu contexto. De um lado, o teatro tinha então pouca concorrência, não havia nada a esperar de uma televisão sonâmbula e totalmente sob controle; e, de outro lado, a resistência ao totalitarismo não foi desprovida de ambiguidades. Colocada pelas suas convicções políticas ou artísticas na coleira do poder, de onde geralmente não podia afastar-se sem bem conhecer seus rompantes, ele queria vê-la funcionando bem próxima. Falhar ou enfraquecer nos apoios seria significar sua brutal condenação. Era necessário se servir da força, mas também das debilidades do sistema, dos conflitos internos. É preciso saber quando se pode resistir. Saber organizar essa resistência no sentido de trabalhar. E ter uma grande reserva de energia - essa que muitas vezes exige todo o exercício da mise en scène.

Liubímov sabia de tudo isso, e possuía, sem dúvida, à parte sua sólida constituição, o dobro da energia normalmente necessária ao trabalho cênico. De seu lado, o poder se defendia neutralizando a força de deflagração do teatro colocando-o, pouco a pouco, numa situação de dissidente "autorizado". Mas ele sabia que chegara ao poder após "ter seduzido" através da emoção, em 1971, com o espetáculo As auroras aqui são calmas, a partir de um conto de B. Vassiliev, conseguindo a adesão da municipalidade local, a de Moscou, que decidiu destinar à trupe uma segunda sala, maior e mais confortável. Liubímov lutou para que não se construísse nas ruínas de seu teatro, a pequena sala, um lugar caloroso, quando a demolição era vista por todos como um vigoroso impacto simbólico de rendição. Ele ganhou a causa mas viu, em seguida, tudo se arrastar, certamente, e a grande sala não ser aberta, ao lado da pequena, a não ser na década seguinte. Complexidade de relações, de estratégias, clareza nas paradas do jogo.

Pulmão da capital e do imenso país, a Tagánka era controlada pelo poder. Mas Liubímov soube resitir, e combateu a censura pé ante pé, palavra por palavra. $E$, no campo de força de seu palco nu, quase sempre vazio, e através dos jogos específicos estabelecidos entre a cena e a sala, tudo parecia falar - cada imagem, cada gesto, cada objeto e até mesmo cada silêncio - para proclamar em voz alta, para além da "zona tagankiana", o que não se podia dizer além dos espaços privados das cozinhas moscovitas. Qualquer ameaça de interdição fazia a sala "esquentar", insuflada por um sentimento de comunidade, dotando o espetáculo de uma energia autêntica, onde a circulação podia se diluir ou se bloquear mesmo quando nas turnês fora da URSS, nos países "capitalistas", onde os códigos e valores eram diferentes. O calor da recepção em Moscou e outras cidades da URSS podiam, às vezes, exceder o valor intríseco do espetáculo. Faz parte da especificidade do espetáculo que ele não exista 
jamais senão no tempo reduzido e infinitamente rico da troca, na medida em que um espetáculo é "magnificado" por um público que enleva os atores, reforça as significações pela qualidade de sua escuta e suas reações, no anonimato coletivo que parece proteger contra possíveis represálias por parte do poder.

Outros encenadores - T. Tovstonogov, O. Efremov, A. Efros, P. Fomenko - trabalhavam em espaços que mantinham por diversos meios conquistados e conservados ou nos lugares para onde se deslocavam, sobrevivendo assim às perseguisões da censura. Liubímov não esteve só nessa paisagem teatral. Mas no teatro-barco onde era capitão, ele não foi somente um artista - o encenador - assitido por um cenógrafo sem igual como foi David Borovski, nem somente por um grupo - um grupo estável -, nem somente de uma arte ou um lugar cênico onde essa arte se exercia em modo principal (uma vez que os atores eram também convidados para as fábricas da periferia e a dar espetáculo nas províncias, ou cada um, separadamente, em Moscou, para as tardes de poesia). Eles abarcaram, assim, o público a que os espetáculos eram precisamente destinados, para o qual foram concebidos).

A grande obra de Liubímov se situa precisamente entre os anos 1960 e 1970, no coração de Moscou e da URSS, numa cidade e num país que perderam a memória, onde a prática da cidadania estava totalmente rarefeita. Ir à Tagánka se assemelhava ao cumprimento de um ato civico e político. Foi também um momento de vida muito intenso, porque mais consciente e mais alegre - não fuga, não sonho -, que aquele que ocorria fora das paredes desse teatro.

Antoine Vitez sublinhou que a Tagánka assumiu o papel de "consciência política e moral da sociedade". Foi através de seu repertório construído, majoritariamente nacional mas incorporando, é claro, os grandes textos de teatro ( $O$ Tartufo, Hamlet), mas sobretudo as obras em prosa e poesia russas e soviéticas, adaptadas ou montadas juntas, que a Tagánka se dirigiu a seu público, colocando-lhe questões cruciais, dialogando com ele. A Tagánka foi um teatro de repertório no sentido mais amplo e forte da palavra: um lugar onde se podia ver ou rever, em seus espetáculos, aquilo que se amou, que intrigou, que não foi cumprido, que se podia aprofundar; um lugar onde o espetáculo pode evoluir no tempo através de um encenador atento ${ }^{4}$, com atores que envelhecem e mudam, como seus espectadores. Assim, A alma boa de Setsuan, espetáculo que serviu de base à fundação da Tagánka em 1964, foi representada durante decênios, com novos intérpretes e, em 1989, por exemplo, praticamente trinta anos após sua criação, ainda arrancando aplausos poderosos crepitando em certas réplicas, tanto a representação ainda tocava o público. Mas ser um teatro de repertório para a Tagánka significou também ser um lugar onde cada nova obra podia ser posta em diálogo, noite após noite, com aquelas que a precederam ou a seguiram na programação da semana ou do ano.

Em 1963-64, o primeiro espetáculo da trupe formada numa promoção do Instituto Teatral Chtchukin de Moscou - os alunos de Liubímov, um grande ator do Teatro de Vakhtángov que fazia "jogos falsos" com a estética do realismo socialista e havia abandonado sua carreira de sucesso para se consagrar ao ensino -, A alma boa de

${ }^{4} \mathrm{O}$ que significa um trabalho específico sobre a encenação, um retrabalhar constante depois da estreia e em cada nova temporada. 
Setsuan, terminou com a mesma convicção do coro de jovens atores, se apropriando juntos do monólogo do ator que faz o epílogo brechtiano :

"Caro público, procure a continuação

Deve existir uma conveniente

É preciso, é preciso."

E a última réplica de Boris Gúdunov, de Pushkin, encenação interditada em 1982 e que não foi retomada senão em 1989, foi dirigida à platéia : "Porque vocês ficam em silêncio? "Liubímov fez ser dita diante da sala fortemente iluminada.

Almejando assim a interpelação, o questionamento do público, a transformação do homem e do mundo num tempo parado, aquele da época de Brejnev ("época da estagnação, como se diz"), a Tagánka tentava espraiar a cena sobre a vida e sobre as ações coerentes para modifica-las. Ela fazia um ato de resistência e oferecia, ao mesmo tempo, a arena do palco para a análise das relações de poder, um dos grandes temas dos anos 1960, que importavam à geração daqueles que, como Liubímov, tinham entrado para o Partido Comunista em 1953, após ter conhecido a proximidade e a solidariedade provocadas pela guerra, pensando que poderiam melhorar as coisas interiores.

Mas, quando se considera o conjunto da história da Tagánka, aparece igualmente outro tipo de recorrência, tanto no repertório quanto nas situações cênicas. Porque a Tagánka buscou, em modo obstinado, um frente a frente com os grandes artistas russos desaparecidos, através do ritual da memória - retratos vestidos, minutos de silêncio, abraços com uma flâmula de lembrança - que tiveram lugar sobre o palco ou nas escadarias do teatro. Esse teatro pleno de vida privilegiou o tema da morte, do desaparecimento e do crime: seja através dos massacres ligados à Guerra, dos crimes de massa, passando pela morte de poetas, assassinados ou suicidados. A Tagánka consagrou grandes espetáculos a Alexander Puchkin, Vladimir Maiakóvski ou, após sua morte, a Vladimir Vyssótski, ator-cantor da trupe, bardo interditado mesmo com discos e recitais anunciados oficialmente, que fizeram flamejar a cena da Tagánka ao se acompanhar sozinho com seu violão em certos espetáculos. Foi ele quem interpretou, entre 1971 e 1980 (data de sua morte), um inesquecível Hamlet vestido de jeans e blusa pretos, entrando em cena cantando o poema Hamlet, escrito pelo poeta Boris Pasternak, tradutor da peça, sobre o qual ele colocara música. Em 1974, Liubímov quis consagrar, juntamente com seu cenógafo David Borovski, um espetáculo a Vsevolod Meyerhold, o encenador-poeta assassinado por Stálin em 1940, mas foi proibido.

Teatro político - no sentido de teatro da polis, da cidade - lugar de reunião necessária e jubilatória, um dos únicos locais onde se podia falar dos "negócios" da cidade e do país, e teatro poético - onde a obra de poetas constituiu o nicho do repertório -, a Tagánka articulou seu trabalho teatral, a escolha de obras, o jogo dos atores e a encenação, sobre esse poderoso diálogo entre ação e memória, mas igualmente caçoando, recusando as ameaças do poder estabelecido, as tesouras da censura e os embustes da "língua de madeira".

Em 1984, após a interdição de três espetáculos (Boris Gúdunov, Vissótski e 0 Suicidado, de N. Erdman), Liubímov deixou a Rússia. Diabólico, o poder colocou à frente do teatro Anatoli Efros, cuja estética era uma antípoda da sua. O encenador, 
exilado, foi destituído; longe de seus atores ele encenou na Inglaterra, na Itália, na Alemanha, obras de Dostoiévski, Puschkin, e numerosas óperas, ao mesmo tempo em que o repertório da Tagánka era esvaziado. Finalmente, em 1988, ele retorna triunfante a Moscou, para assumir as estreias dos espetáculos interditados. Mas, em 1992, o Teatro da Tagánka de Moscou, na sequencia de querelas internas e fratricidas, foi dividido em dois conjuntos inimigos: um, dirigido pelo seu chefe histórico, Yuri Petrovitch Liubímov, continuou a levar o nome de "Teatro da Tagánka" e a representar, na pequena sala, o repertório que durante os anos sessenta e setenta marcaram e nutriram profundamente a vida do público soviético, totalmente apresentado de novo. A outra ocupou o grande teatro, sob o nome de Confraria dos Atores da Tagánka. Longamente sedimentado pela luta, ao mesmo tempo poderosa e tenaz contra o poder repressivo, o grupo desfruta agora da liberdade reencontrada (após a perestróika), exprimindo através de sua divisão o estado de caos, de violência, de inquietações e novas dissenções que despedaçaram a sociedade russa. A história da Tagánka seguiu e refletiu, ponto por ponto, aquela da URSS após o degelo, e depois a da Rússia pós-perestróika.

Em seu retorno, Liubímov recebeu honrarias, condecorações - entre outras o Prêmio de Estado do Kremlim, Ordem do Mérito da Pátria em 1997 -, mas o teatro ficou inexoravelmente cindido depois de 1992, agonizante, e a fronteira que materializa dentro do edifício a grave discórdia, como sempre tecida pelas cabalas entre facções políticas, permanece. Infatigável, o encenador continuou dirigindo, em seu pequeno teatro e, após, fora dele (porque a cisão se tornou definitiva) até a véspera de sua morte. Ele continuou a intervir nas discussões públicas. Mas a ligação com a época, tão intensa durante vinte anos, foi perdida - essa ligação com o presente que se alimenta da consciência com o passado enterrado - e no caso da URSS, interditado - que o teatro possui quando é contemporâneo. E a história de um grupo tornou-se aquela de um homem, de um grande artista de teatro. Mas o impacto político arrefeceu.

Os russos ainda lembram dessa história trágica, bem como daqueles achados felizes que se seguiram a 1988-1989, com duas estreias diferentes - Boris Gúdunove O Vivo -, sobre o qual já destacamos como um fato único na história do teatro? E das discórdias que se exacerbaram, mantendo a divisão, a partilha do grupo, como se fala da sepração de um país? Liubímov morreu em 2014, e o Teatro da Tagánka tornou-se uma casca vazia. E, no site de Internet do teatro todos os arquivos foram apagados, em abril de 2014. A obra de Liubímov e sua equipe, que não é mais representada, teria se tornado novamente subversiva?

Nascido em 1917, Liubímov atravessou toda a história do século: ele viu seu avô, um antigo servo ser condenado como kulak, seus pais serem presos; e, ator adulado no Teatro Vakhtángov, colocou-se durante quarenta anos a questão do embuste que travou com o realismo socialista, colocando-se, junto com seus alunos, na pesquisa de um outro teatro. Ele dirigiu um grupo cujo nome foi um complemento indissociáel, durante vinte anos, do nome "URSS". Ele viu se desenvolver uma nova sociedade.

Com o grupo unido ele fabricou, durante vinte anos, um teatro dirigido ao público que, em seu confronto exigente, tornou-se seu grande ressonador, segundo uma expressão que Vsevolod Meyerhold adorava. “De que estado teríamos nós salta- 
do durante o período da estagnação, se não tivesse existido a Tagánka", escreveu em 1989 o crítico de teatro Boris Zinguerman. Outra crítica, Irina Ouvarova, insistiu sobre essa necessidade: "precisa-se desse teatro como se precisa de pão". O engajamento político veio de par com os graves riscos a que se expôs - que a publicação dos arquivos concernentes às relações de Liubímov com o Partido e a censura fornecem hoje em dia uma ideia -, com a coragem de assumi-los, juntos, e do conhecimento de uma arte do teatro complexa, musical, ligada às descobertas de Meyerhold (durante muito tempo o poder interditou o Teatro de exibir em seu foyer um seu retrato), uma arte do teatro onde a visão do espectador devia, para enganar os censores, saber tratar-se de palavras para fazer crescer a força das imagens no jogo dos atores.

Recebido em: 02/05/2016

Aprovado em: 02/07/2016 